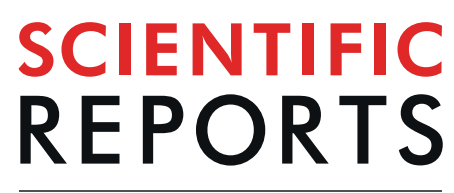

natureresearch

\title{
Polar mesoporous zinc sulfide nanosheets encapsulated in reduced graphene oxide three- dimensional foams for sulfur host
}

\begin{abstract}
Limin Mao, Fei Wang \& Jian Mao $\mathbb{D}^{*}$
Lithium-sulfur (Li-S) batteries exhibit the high specific capacity and energy density, but prevented by the low coulombic efficiency and weak cycle life. Herein, we fabricate reduced graphene oxide ( $r$-GO) three-dimensional (3D) foams encapsulating polar mesoporous zinc sulfide (ZnS) nanosheets and subsequently utilize the $\mathrm{ZnS} / \mathrm{r}-\mathrm{GO}$ foams to load sulfur ( $\mathrm{ZnS} / \mathrm{r}-\mathrm{GO} / \mathrm{S}$ ) as cathodes for improving the performance of $\mathrm{Li}-\mathrm{S}$ batteries. The mesoporous diameter of the $\mathrm{ZnS}$ nanosheets is approximately $10 \sim 30 \mathrm{~nm}$ and lots of pores in the 3D foams are observed. The porous structure provides abundant sites to adsorb and accommodate sulfur species. The cathode of the $\mathrm{ZnS} / \mathrm{r}-\mathrm{GO} / \mathrm{S}$ exhibits $1259 \mathrm{~mA} \mathrm{~h} \mathrm{~g}^{-1}$ of initial capacity and $971.9 \mathrm{~mA} \mathrm{~h} \mathrm{~g}^{-1}$ of the reversible capacity after 200 cycles at $0.1 \mathrm{C}\left(1 \mathrm{C}=1675 \mathrm{~mA} \mathrm{~g}^{-1}\right)$. At $1 C$, it still exhibits the tiny capacity decay rate of $0.019 \%$ per cycle after 300 cycles. This work may be adopted to combine the nonpolar and polar materials as a 3D network structure for high-performance Li-S batteries.
\end{abstract}

Lithium-sulfur (Li-S) batteries, as the most promising next-generation rechargeable batteries, possess an ultrahigh theoretical specific capacity of $1675 \mathrm{~mA} \mathrm{~h} \mathrm{~g}$-1 and excellent theoretical energy density of $2600 \mathrm{Wh} \mathrm{Kg}^{-1}$, up to five times greater than commercial LIBs $\left(387 \mathrm{Wh} \mathrm{Kg}^{-1} \text { for } \mathrm{LiCoO}_{2} / \mathrm{C} \text { battery }\right)^{1,2}$. In addition, sulfur element is abundant, low-cost and environmentally inert ${ }^{3}$. Therefore, Li-S batteries are supposed to most promising candidate energy device to satisfy the request of electronic equipment and the demand of preferable pure electric vehicles ${ }^{4}$. However, Li-S batteries are still impeded by the low coulombic efficiency and the poor cycling stability, due to three factors: (1) the insulation of sulfur and its final product $\mathrm{Li}_{2} \mathrm{~S} / \mathrm{Li}_{2} \mathrm{~S}_{2}$, (2) large volume change during charge and discharge, and (3) the shuttling effect. The insulation of sulfur and $\mathrm{Li}_{2} \mathrm{~S}_{2} / \mathrm{Li}_{2} \mathrm{~S}$ limits the redox reaction, causing the low utilization of active materials. Consequently, uniform dispersion of sulfur and good electrical contact with conductive matrixes are essential ${ }^{5}$. Volume change of sulfur under alloying is approximately $80 \%$, making the electrode broken easily ${ }^{6}$. Many porous materials and internal void nanoarchitectures were designed to accommodate the expansion ${ }^{7}$. Shuttling effect is the critical issue in Li-S batteries, which causes low charge efficiency and poor cyclic stability. Many researches manifested that physical trapping by porous nanostructure and chemical affinity by polar materials can hinder shuttling effect availably ${ }^{8,9}$.

Up to now, sulfur was loaded into various materials with diverse morphologies, including carbonaceous materials $^{10-12}$, conductive polymers ${ }^{13-15}$, metal oxides ${ }^{16,17}$, and metal sulfides ${ }^{18,19}$, etc. Carbonaceous frameworks were popular on account of their good conductivity and abundant morphologies, such as meso/microporous ${ }^{20}$, fiber-like and foam-like structure ${ }^{21,22}$. Graphene with high surface area, chemical stability, mechanical strength and flexibility, was utilized as a common energy material ${ }^{23}$. Nevertheless, the graphene is nonpolar nature, so polysulfides are easy to escape from the surface of graphene ${ }^{24}$. Oxides and sulfides are better in restraining polysulfides migrating due to their polarity ${ }^{19,25}$. Metal sulfides have a strong affinity for polysulfides caused by strong sulfiphilic property, but suffering from low conductivity ${ }^{26}$. Therefore, studies in combination the graphene and polar materials to achieve the good conductivity and reduce polysulfides shuttling were prominent ${ }^{27}$.

Herein, we designed a three-dimensional (3D) porous foams, constructed by high conductive reduced graphene oxide (r-GO), to encapsulate polar mesoporous $\mathrm{ZnS}$ nanosheets by a facile water bath method. Then, the $\mathrm{ZnS} / \mathrm{r}$-GO foams loaded sulfur as composite electrodes for high-performance Li-S batteries. The r-GO foam and $\mathrm{ZnS}$ nanosheets were used to load sulfur as contrasted. The schematic illustration was shown in Fig. 1. The 


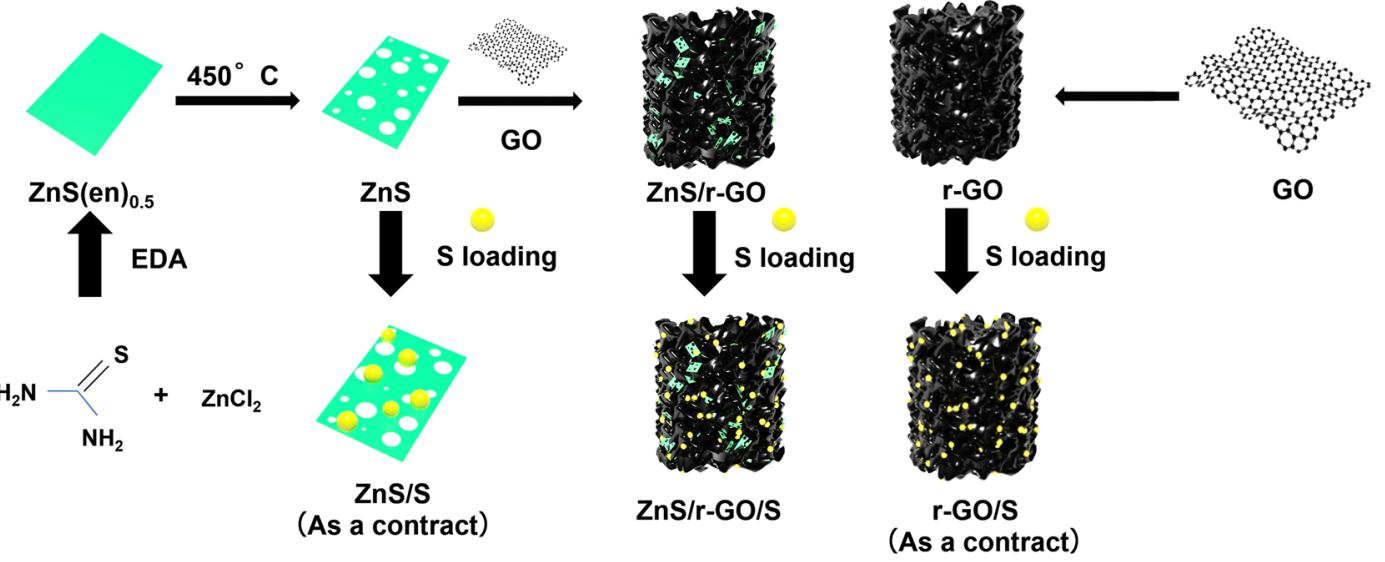

Figure 1. Schematic illustration showing the preparation $\mathrm{ZnS} / \mathrm{S}, \mathrm{r}-\mathrm{GO} / \mathrm{S}$ and $\mathrm{ZnS} / \mathrm{r}-\mathrm{GO} / \mathrm{S}$ foams composites.

mesoporous $\mathrm{ZnS}$ nanosheets were synthesized by sintering zinc sulfide $\left(\mathrm{C}_{2} \mathrm{H}_{4}\left(\mathrm{NH}_{2}\right)_{2}\right)_{0.5}\left(\mathrm{ZnS}(\text { en })_{0.5}\right)$ precursor with a superior catalysis ${ }^{28,29}$. The strong interaction with soluble polysulfides and catalytic activation of $\mathrm{ZnS}$ makes sure the sulfur utilization and stable cycle performance ${ }^{30,31}$. The $3 \mathrm{D}$ porous $\mathrm{r}$-GO network possessed high conductivity, promoting the rapid diffusion of $\mathrm{Li}^{+}$, but also providing the abundant sites to accommodate the sulfur species and release the expansion. The cathode of the $3 \mathrm{D} \mathrm{ZnS} / \mathrm{r}-\mathrm{GO} / \mathrm{S}$ foams represented excellent electrochemical performance, such as the high initial capacity of $1259 \mathrm{~mA} \mathrm{~h} \mathrm{~g}^{-1}$ and a stable capacity retention of $971.9 \mathrm{~mA} \mathrm{~h} \mathrm{~g}^{-1}$ after 200 cycles at $0.1 \mathrm{C}\left(1 \mathrm{C}=1675 \mathrm{~mA} \mathrm{~g}^{-1}\right)$, remarkable coulombic efficiency of close to $100 \%$ as well as low capacity fading rate of $0.019 \%$ per cycle after 300 cycles at $1 \mathrm{C}$.

\section{Results and Discussion}

The SEM and TEM, HR-TEM images were shown in Fig. 2. The ZnS(en) $)_{0.5}$ was composed of large quantities of smooth nanosheets with the thickness of $60 \sim 100 \mathrm{~nm}$, and the large range of a few to a dozen micrometers in lateral dimensions (Fig. 2a).The mesoporous $\mathrm{ZnS}$ succeeded to the similar sheet nanostructure in Fig. 2b, and the porosities were triggered by the decomposition of ethylenediamine (EDA) ${ }^{32}$, which could provide more sites to adsorb and catalyze polysulfides. The insert TEM image showed that the pore diameter was approximately $10 \sim 30 \mathrm{~nm}$. HRTEM observation in Fig. 2c showed well-resolved lattice planes with a lattice spacing of $0.33 \mathrm{~nm}$ (Corresponding to (100) plane of ZnS). The SEM of the ZnS/r-GO foams (Fig. 2d) indicated that the ZnS nanosheets were encapsulated in the $\mathrm{r}-\mathrm{GO}$ foams. The insert was the cross section SEM of ZnS/r-GO, manifested the $3 \mathrm{D}$ porous structure of the prepared composite, which played a vital role in accommodating sulfur and confinement physically to polysulfides. The loaded sulfur was distributed in the $\mathrm{ZnS} / \mathrm{r}$-GO composite as Fig. 2e. The EDS mapping (Fig. 2f) of $\mathrm{Zn}$ and S elements elucidated the uniform distribution of sulfur and the $\mathrm{ZnS}$ nanosheets.

The XRD patterns of these samples were shown in Fig. 3a. The $\mathrm{ZnS}(\mathrm{en})_{0.5}$ was indexed in the orthorhombic system, consistent with the previous studies ${ }^{29,33}$. After $450^{\circ} \mathrm{C}$ annealing, the EDA was decomposed and the product was transformed to wurtzite $\mathrm{ZnS}^{34}$. Compared with the XRD pattern of the $\mathrm{r}-\mathrm{GO}$, the $\mathrm{ZnS} / \mathrm{r}-\mathrm{GO}$ composite had no obvious peak at approximate $26^{\circ}$, corresponding to (002) plane of r-GO. It probably resulted from the $\mathrm{ZnS}$ nanosheets preventing the restocking of the $\mathrm{r}-\mathrm{GO}$ nanosheets ${ }^{35}$. The sulfur of the $\mathrm{ZnS} / \mathrm{r}-\mathrm{GO} / \mathrm{S}$ was indexed to the orthorhombic system (JCPDS card 08-0247).

The thermogravimetry (TG) curves of the $\mathrm{ZnS} / \mathrm{r}-\mathrm{GO} / \mathrm{S}$ composite and $\mathrm{r}-\mathrm{GO}$ in $\mathrm{N}_{2}$ atmosphere were shown in Fig. 3b. The plummet of the $\mathrm{ZnS} / \mathrm{r}-\mathrm{GO} / \mathrm{S}$ composite mainly due to the evaporation of the sulfur. The curve of the r-GO presented near-linear decline, which may cause by the decomposed of the unreduced oxygen functional group. Compared with the curve of the $\mathrm{r}-\mathrm{GO}$, the decline of the $\mathrm{ZnS} / \mathrm{r}-\mathrm{GO} / \mathrm{S}$ composite was comprised of $11 \%$ and $61 \%$ resulted from the $\mathrm{r}-\mathrm{GO}$ and sulfur, respectively. After heated to over $300^{\circ} \mathrm{C}$, the almost parallel curves also indicated that the declined weight of the $\mathrm{ZnS} / \mathrm{r}-\mathrm{GO} / \mathrm{S}$ composite influenced by the r-GO.

$\mathrm{X}$-ray photoelectron spectroscopy (XPS) was conducted to further investigate the chemical states of the $\mathrm{ZnS} / \mathrm{r}-\mathrm{GO}$ foams in Fig. 4. The wide spectra (Fig. 4a) showed the presence of C $1 \mathrm{~s}, \mathrm{O} 1 \mathrm{~s}, \mathrm{Zn} \mathrm{2p}$ and S 2p peaks. The $\mathrm{C} 1 \mathrm{~s}$ spectrum (Fig. $4 \mathrm{~b}$ ) exhibited a noteworthy peak at $284.5 \mathrm{eV}$, ascribed to $\mathrm{C}-\mathrm{C} / \mathrm{C}=\mathrm{C}$. Other peaks located at 285.9 and $289.3 \mathrm{eV}$ were ascribed to $\mathrm{C}-\mathrm{O} / \mathrm{C}-\mathrm{O}-\mathrm{C}$ and $\mathrm{O}=\mathrm{C}-\mathrm{O} / \mathrm{C}=\mathrm{O}$, respectively. Figure $4 \mathrm{c}$,d showed the $\mathrm{S} 2 \mathrm{p}$ and $\mathrm{Zn} 2 \mathrm{p}$ spectra of $\mathrm{ZnS} / \mathrm{r}-\mathrm{GO}$ composite and $\mathrm{ZnS}$ nanosheets. The peak separation of the peaks at 1022.5 and $1045.9 \mathrm{eV}$ in $\mathrm{Zn} 2 \mathrm{p}$ spectrum of $\mathrm{ZnS} / \mathrm{r}-\mathrm{GO}$ composite was $23.0 \mathrm{eV}$, which was originated from the $\mathrm{Zn} 2 \mathrm{p}_{3 / 2}$ and $\mathrm{Zn}$ $2 \mathrm{p}_{1 / 2}$ of $\mathrm{ZnS}^{36}$. Compared with the $\mathrm{ZnS}$ nanosheets, there was a positive shift of 1.05 and $0.98 \mathrm{eV}$ for $\mathrm{Zn} 2 \mathrm{p}_{3 / 2}$ and $\mathrm{Zn} 2 \mathrm{p}_{1 / 2}$ of $\mathrm{ZnS} / \mathrm{r}-\mathrm{GO}$ composite, respectively. Correspondingly, the $\mathrm{S} 2 \mathrm{p}$ could be deconvoluted into the peaks at 162.0 and $162.9 \mathrm{eV}$, assigned to $\mathrm{S} 2 \mathrm{p}_{3 / 2}$ and $\mathrm{S} 2 \mathrm{p}_{1 / 2}$ of $\mathrm{ZnS}$. The peaks in $\mathrm{S} 2 \mathrm{p}$ spectrum of $\mathrm{ZnS} / \mathrm{r}-\mathrm{GO}$ composite also shifted to the higher binding energy. These indicated the electronically coupled between $\mathrm{ZnS}$ and $\mathrm{r}-\mathrm{GO}^{37}$.

The electrochemical performance of $\mathrm{ZnS} / \mathrm{r}-\mathrm{GO} / \mathrm{S}$ and $\mathrm{ZnS} / \mathrm{S}$ cathodes was displayed in Fig. 5 . The cycle performance of $\mathrm{ZnS} / \mathrm{r}-\mathrm{GO} / \mathrm{S}, \mathrm{r}-\mathrm{GO} / \mathrm{S}$ and $\mathrm{ZnS} / \mathrm{S}$ at $0.1 \mathrm{C}$ were exhibited in Fig. 5a. The initial specific capacities of $\mathrm{ZnS} / \mathrm{r}-\mathrm{GO} / \mathrm{S}, \mathrm{r}-\mathrm{GO} / \mathrm{S}$ and $\mathrm{ZnS} / \mathrm{S}$ were $1259.4,1205.3$ and $910.2 \mathrm{~mA} \mathrm{~h}^{-1}$, respectively, retained the reversible capacity of $1059.2,879.0$ and $626.6 \mathrm{~mA} \mathrm{~h} \mathrm{~g}^{-1}$ after 100 cycles. The $\mathrm{ZnS} / \mathrm{S}$ cathode exhibited a lower initial specific capacity and dramatic capacity fading in the second cycle. However, between 3 and 100 cycles, the 


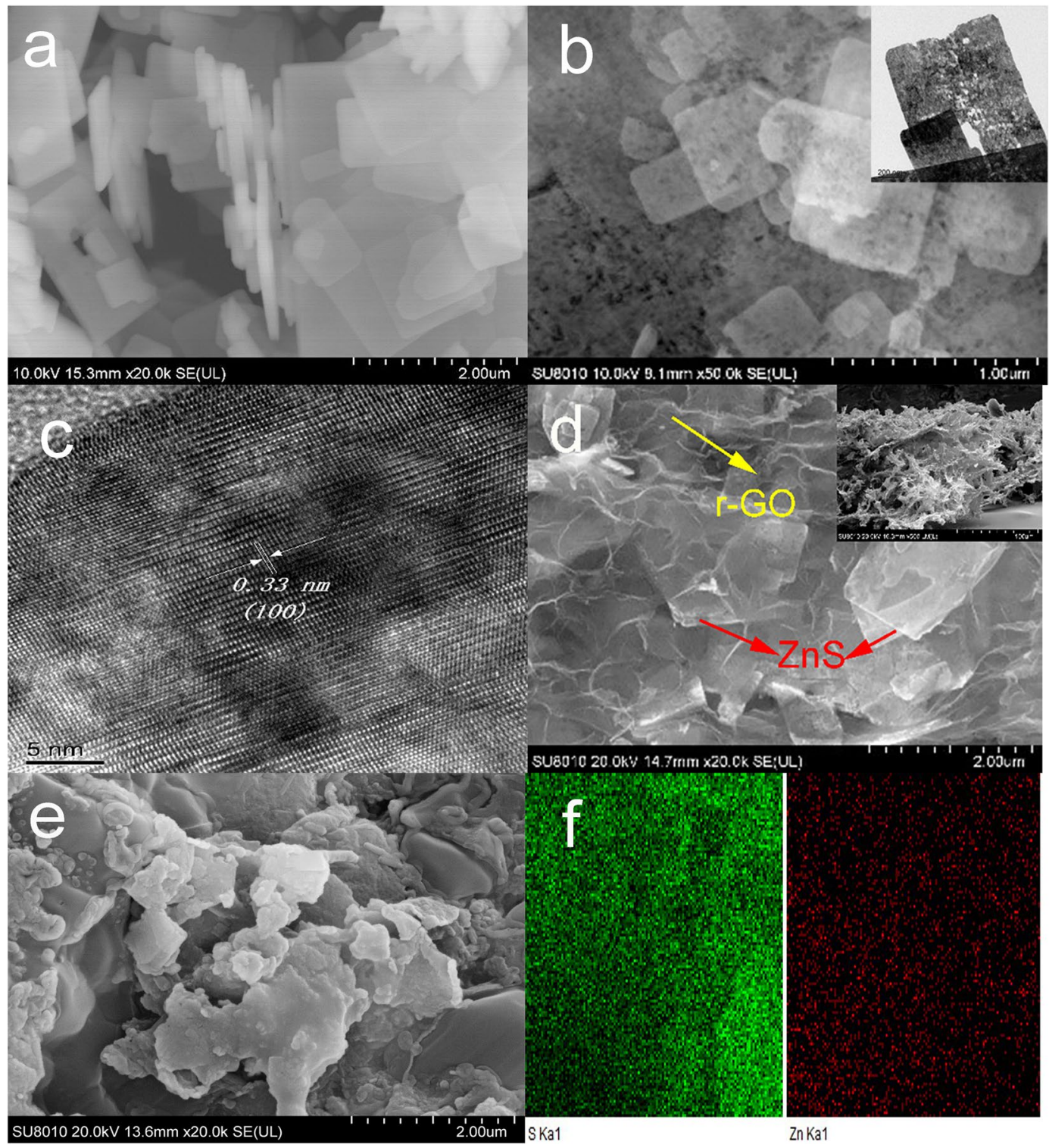

Figure 2. SEM and TEM images of the samples. (a) $\mathrm{ZnS}(\mathrm{en})_{0.5}$, (b) mesoporous $\mathrm{ZnS}$, the insert is TEM image of mesoporous ZnS. (c) HRTEM image of mesoporous ZnS, (d) SEM images of ZnS/r-GO, the insert is the cross section SEM of ZnS/r-GO. ZnS nanosheets were guided by red arrows, and r-GO was guided by yellow arrows. (e) SEM image of $\mathrm{ZnS} / \mathrm{r}-\mathrm{GO} / \mathrm{S}$. (f) the EDS mapping of (e).
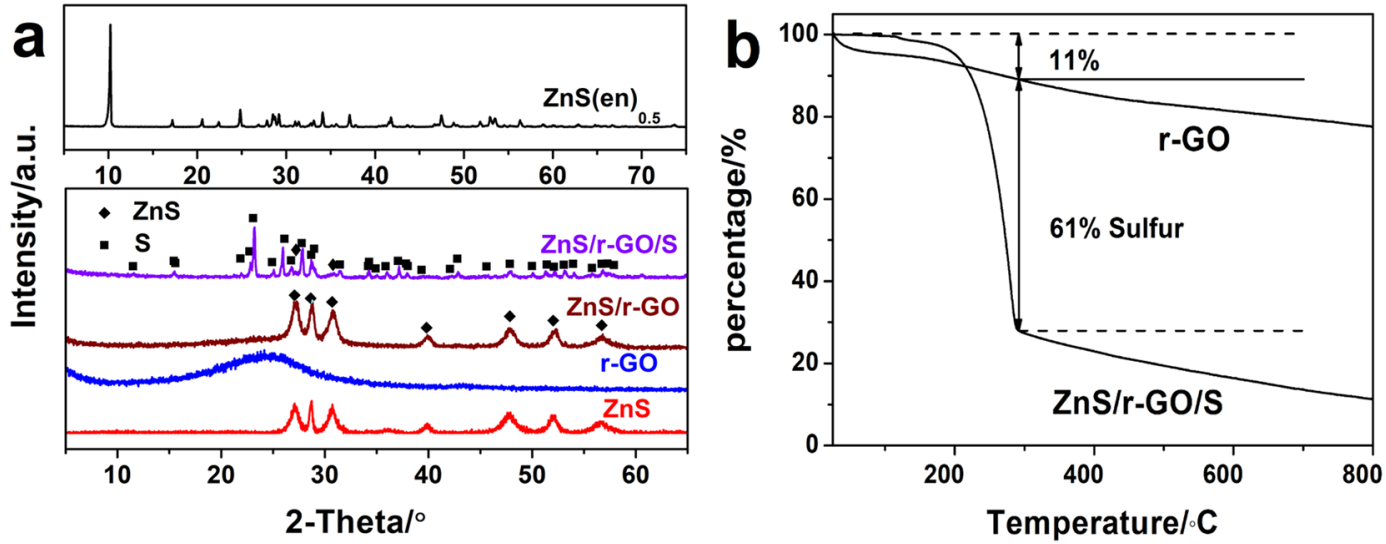

Figure 3. XRD patterns and TG curves of the samples. (a) XRD patterns of $\mathrm{ZnS}(\mathrm{en})_{0.5}, \mathrm{ZnS}, \mathrm{r}-\mathrm{GO}, \mathrm{ZnS} / \mathrm{r}-\mathrm{GO}$ and $\mathrm{ZnS} / \mathrm{r}-\mathrm{GO} / \mathrm{S}$. (b) TG curves of $\mathrm{ZnS} / \mathrm{r}-\mathrm{GO} / \mathrm{S}$ and r-GO. 

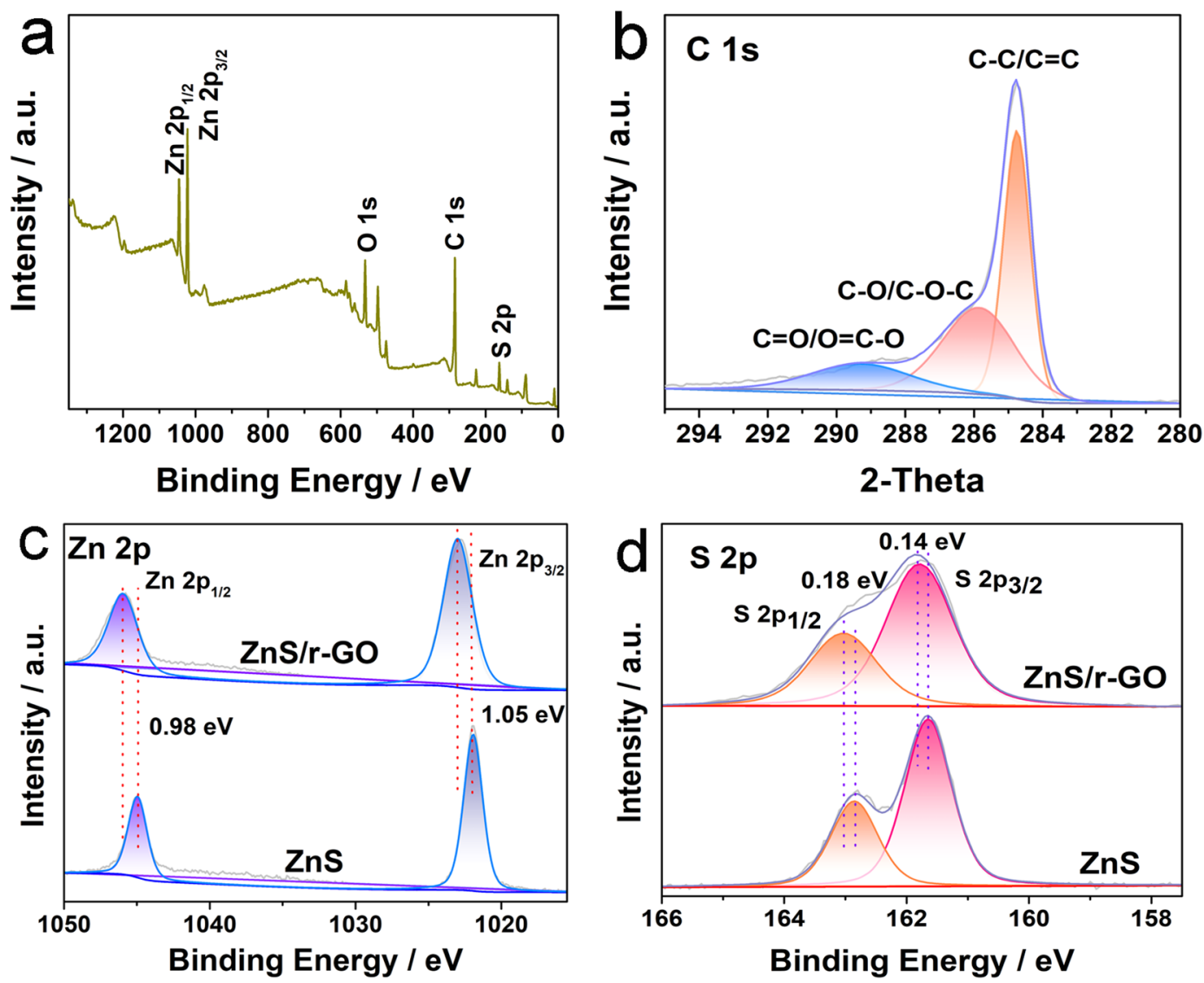

Figure 4. XPS spectra of the $\mathrm{ZnS} / \mathrm{r}-\mathrm{GO}$ and $\mathrm{ZnS}$ composite. (a) Wide spectrum of $\mathrm{ZnS} / \mathrm{r}-\mathrm{GO}$. (b) C $1 \mathrm{~s}$ spectrum of ZnS/r-GO. (c,d) S 2p and Zn 2p spectra of ZnS/r-GO composite and ZnS nanosheets.

specific capacity maintained stable, suggesting that the $\mathrm{ZnS}$ had a strong affinity and good catalytic activity to polysulfides. The almost coincident galvanostatic charge/discharge curves of the $\mathrm{ZnS} / \mathrm{S}$ cathode at 10th, 50th and 100th (Fig. 5b) confirmed the stable cycle. Because of the high specific surface area and high conductivity of the $\mathrm{r}-\mathrm{GO} 3 \mathrm{D}$ network, the $\mathrm{ZnS} / \mathrm{r}-\mathrm{GO} / \mathrm{S}$ and $\mathrm{r}-\mathrm{GO} / \mathrm{S}$ exhibited a higher initial specific capacity. In the first few cycles, both $\mathrm{ZnS} / \mathrm{r}-\mathrm{GO} / \mathrm{S}$ and $\mathrm{r}-\mathrm{GO} / \mathrm{S}$ showed a severe capacity fading, after that, the specific capacity increased gradually. The reasons were as follows: as the electrolyte penetrated, the sulfur loaded in the 3D foams would gradually react with $\mathrm{Li}^{+}$; and for the $\mathrm{ZnS} / \mathrm{r}-\mathrm{GO} / \mathrm{S}$ cathode, owing to the strong adsorption and catalysis of $\mathrm{ZnS}^{31,38}$, the mesoporous $\mathrm{ZnS}$ encapsulated in $3 \mathrm{D}$ foams would gradually adsorb polysulfides dissolving in electrolyte and catalyze the conversion of sulfur redox ${ }^{30}$. The above was also proved by the manifested second charge/discharge voltage profiles at the 50th and 100th cycle of the $\mathrm{ZnS} / \mathrm{r}-\mathrm{GO} / \mathrm{S}$ cathode, which were longer than that at the 10th cycle with the similar first voltage profiles (Fig. 5c). The 50th and 100th cycle displayed specific capacities of 607.9 and $597.6 \mathrm{~mA} \mathrm{~h} \mathrm{~g}^{-1}$ at the second plateau, nonetheless the second plateau of the 10th only discharged $323.9 \mathrm{~mA} \mathrm{~h}$ $\mathrm{g}^{-1}$. The synergistic effect of the high conductive 3D network and strong-sulfiphilic $\mathrm{ZnS}$ made the $\mathrm{ZnS} / \mathrm{r}-\mathrm{GO} / \mathrm{S}$ cathode deliver more excellent electrochemical performance. Even after 200 cycles, the reversible capacity of the $\mathrm{ZnS} / \mathrm{r}-\mathrm{GO} / \mathrm{S}$ was $971.9 \mathrm{~mA} \mathrm{~h}^{-1}$.

$\mathrm{CV}$ curves of the $\mathrm{ZnS} / \mathrm{r}-\mathrm{GO} / \mathrm{S}$ were recorded at a scan rate of $0.1 \mathrm{mV} \mathrm{s}^{-1}$ in the potential range of $1.7 \sim 2.7 \mathrm{~V}$ (vs. $\mathrm{Li} / \mathrm{Li}^{+}$). The typical redox reaction of sulfur cathodes was presented in Fig. $5 \mathrm{~d}$. In the first cycle, two reduction peaks at $2.29 \mathrm{~V}$ and $2.02 \mathrm{~V}$ were observed, ascribing to the formation of long-chain lithium polysulfides and the further reduction to the short-chain lithium sulfides, respectively. In the third cycle, the reduction peak at $2.29 \mathrm{~V}$ shifted to higher potential $(2.32 \mathrm{~V})$. It demonstrated faster electrochemical kinetics and lower cell polarization, meaning the better cycle reversibility of the $\mathrm{ZnS} / \mathrm{r}-\mathrm{GO} / \mathrm{S}$ cathode ${ }^{11}$.

The long-term cycling performance of the $\mathrm{ZnS} / \mathrm{r}-\mathrm{GO} / \mathrm{S}$ at $1 \mathrm{C}$ after activation in first three cycles at $0.1 \mathrm{C}$ was shown in Fig. 6a. After 300 cycles, a discharge specific capacity of $646.3 \mathrm{~mA} \mathrm{~h} \mathrm{~g}^{-1}$ with $\sim 100 \%$ coulombic efficiency was remained, corresponding to a low capacity fading of $0.019 \%$ per cycle. The rate capacity (Fig. $6 \mathrm{~b}$ ) of the $\mathrm{ZnS} / \mathrm{r}-\mathrm{GO} / \mathrm{S}$ was measured at different current rate in the potential range of $1.7 \sim 2.7 \mathrm{~V}\left(\mathrm{vs}\right.$. $\left.\mathrm{Li} / \mathrm{Li}^{+}\right)$. When the rate turned back to $0.1 \mathrm{C}$ after each 10 cycles at $0.1 \mathrm{C}, 0.2 \mathrm{C}, 0.5 \mathrm{C}$ and $1 \mathrm{C}$, a discharge capacity of approximately $800 \mathrm{~mA} \mathrm{~h} \mathrm{~g}^{-1}$ was recovered, indicating the stable rate performance.

The $\mathrm{Li}_{2} \mathrm{~S}_{6}$ adsorption was measured to visually observe the affinity of the $\mathrm{ZnS} / \mathrm{r}-\mathrm{GO}, \mathrm{r}-\mathrm{GO}$ and $\mathrm{ZnS}$ to polysulfides, and the UV-vis spectra were carried out to test the concentration of $\mathrm{Li}_{2} \mathrm{~S}_{6}$ solutions (Shown in Fig. $6 \mathrm{c}$ ). In the inset photograph, the noticeable fade in color of the $\mathrm{Li}_{2} \mathrm{~S}_{6}$ solutions was observed after adding the $\mathrm{ZnS} / \mathrm{r}$-GO and r-GO due to the disproportionation of the polysulfides ${ }^{39}$ and the adsorption of samples. The affinity of r-GO 

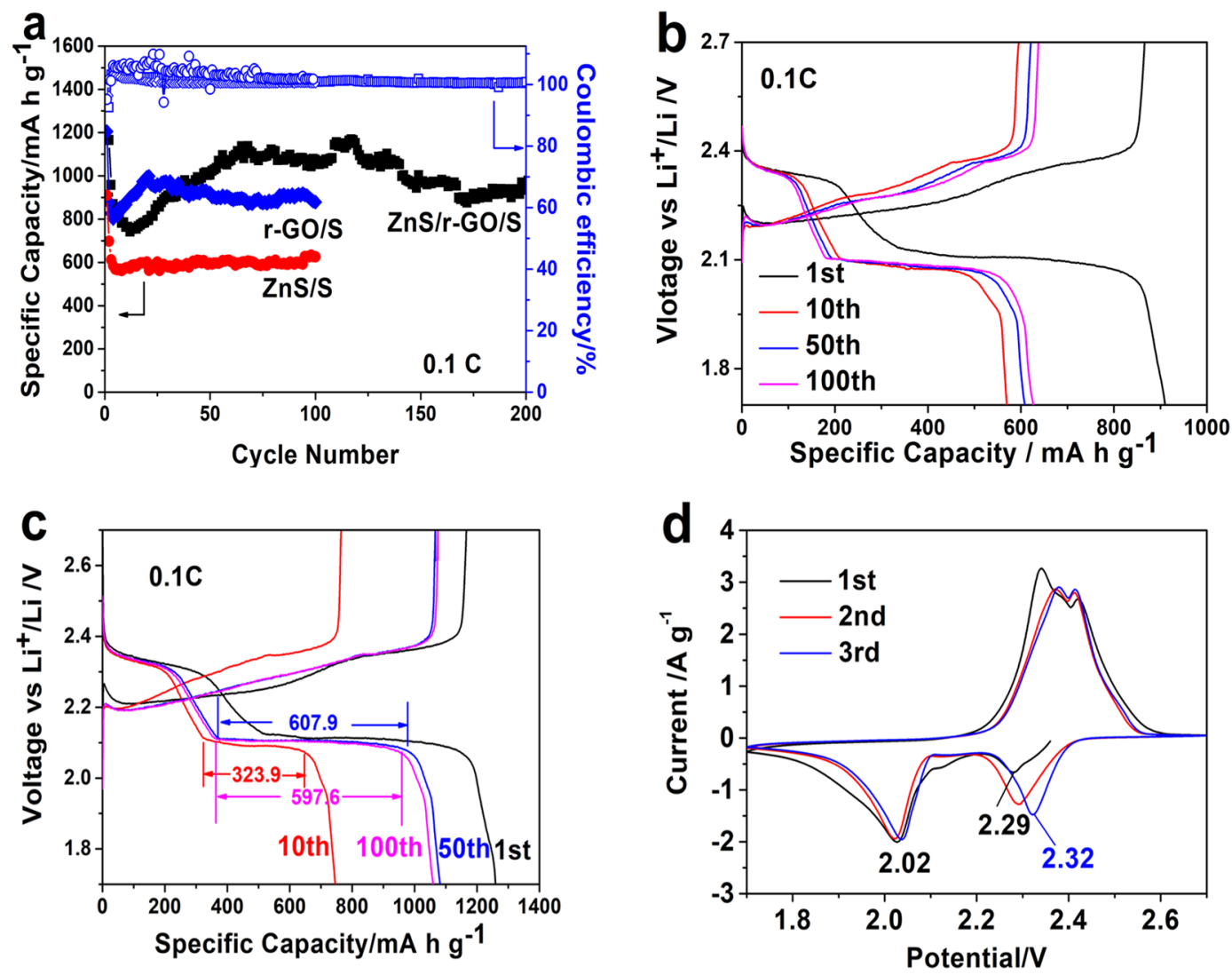

Figure 5. Electrochemical performance of $\mathrm{ZnS} / \mathrm{r}-\mathrm{GO} / \mathrm{S}, \mathrm{r}-\mathrm{GO} / \mathrm{S}$ and $\mathrm{ZnS} / \mathrm{S}$ electrodes. (a) Cycle performance at $0.1 \mathrm{C}$ of $\mathrm{ZnS} / \mathrm{r}-\mathrm{GO} / \mathrm{S}, \mathrm{r}-\mathrm{GO} / \mathrm{S}$ and $\mathrm{ZnS} / \mathrm{S}$ electrodes, respectively. (b,c) Galvanostatic charge/discharge profiles of $\mathrm{ZnS} / \mathrm{S}$ and $\mathrm{ZnS} / \mathrm{r}-\mathrm{GO} / \mathrm{S}$ cathode at $0.1 \mathrm{C}$. (d) $\mathrm{CV}$ curves of $\mathrm{ZnS} / \mathrm{r}-\mathrm{GO} / \mathrm{S}$ electrode.

to plysulfides may be caused by the higher specific area. On the other hand, the change in color of the $\mathrm{Li}_{2} \mathrm{~S}_{6}$ solution of $\mathrm{ZnS}$ treatment was lighter. In the UV-vis spectra, a strong absorbance was observed at 420 and $465 \mathrm{~nm}$ in fresh $\mathrm{Li}_{2} \mathrm{~S}_{6}$ solution, which ascribed to the adsorption peaks of the $\mathrm{Li}_{2} \mathrm{~S}_{6}$. The absorbance of $\mathrm{ZnS}$ was declined slightly, and the peaks were still visible. For the solutions after the r-GO and $\mathrm{ZnS} / \mathrm{r}-\mathrm{GO}$ treatment, the peak almost disappeared, indicating that the $\mathrm{r}-\mathrm{GO}$ and $\mathrm{ZnS} / \mathrm{r}-\mathrm{GO}$ foams had strong affinity to $\mathrm{Li}_{2} \mathrm{~S}_{6}$. From the UV spectra, the $\mathrm{ZnS} / \mathrm{r}-\mathrm{GO}$ foams combining the polarity of $\mathrm{ZnS}$ and the high specific surface area of $\mathrm{r}-\mathrm{GO}$ exhibited the best absorptivity to the $\mathrm{Li}_{2} \mathrm{~S}_{6}$.

In summary, the $3 \mathrm{D}$ foams comprised by polar mesoporous $\mathrm{ZnS}$ nanosheets and r-GO was fabricated, then the sulfur was loaded into the foams as the Li-S batteries cathodes. The pore diamter of the mesoporous $\mathrm{ZnS}$ nanosheets was 10-30 nm and the $\mathrm{ZnS} / \mathrm{r}$-GO composite possessed lots of pores. The $3 \mathrm{D} \mathrm{ZnS} / \mathrm{r}$-GO foams loaded sulfur exhibited excellent electrochemical properties, initial specific capacity of $1259 \mathrm{~mA} \mathrm{~h} \mathrm{~g}^{-1}$ and a reversible capacity of $971.9 \mathrm{~mA} \mathrm{~h} \mathrm{~g}^{-1}$ after 200 cycles at $0.1 \mathrm{C}$, due to the polar adsorption to polysulfides by the mesoporous $\mathrm{ZnS}$ and the excellent $\mathrm{Li}^{+}$or electrons diffusion of the $\mathrm{r}-\mathrm{GO}$ foams. This work may provide a way to combine the nonpolar and polar materials as a $3 \mathrm{D}$ network structure for high-performance Li-S batteries.

\section{Methods}

Preparation of the $\mathrm{ZnS}(\mathrm{en})_{0.5}$, mesoporous $\mathrm{ZnS}$ nanosheets, r-GO and ZnS/r-GO 3D foams. EDA as solvent, the mesoporous $\mathrm{ZnS}$ nanosheets were synthesized by solvothermal and subsequent calcination ${ }^{28} .2 \mathrm{mmol}$ $\mathrm{ZnCl}_{2}$ and $4 \mathrm{mmol} \mathrm{CS}\left(\mathrm{NH}_{2}\right)_{2}$ were mixed uniformly, then dissolved in $60 \mathrm{ml} \mathrm{EDA} \mathrm{with} \mathrm{ultrasonic} \mathrm{for} 30 \mathrm{~min}$. The solution was quickly poured into $100 \mathrm{~mL}$ autoclave, solvothermal at $180^{\circ} \mathrm{C}$ for $12 \mathrm{~h}$. After centrifuging and cleaning, drying at $60^{\circ} \mathrm{C}$ for hours, the $\mathrm{ZnS}(\mathrm{en})_{0.5}$ precursor was obtained. The mesoporous $\mathrm{ZnS}$ nanosheets were got by calcinating the $\mathrm{ZnS}(\mathrm{en})_{0.5}$ at $450^{\circ} \mathrm{C}$ for $30 \mathrm{~min}$ in air. The $\mathrm{ZnS} / \mathrm{r}-\mathrm{GO} 3 \mathrm{D}$ foams were synthesized by a facile excess ascorbic acid reduction method and the mass ratio of the $\mathrm{ZnS}$ and GO was 1:1. The mixture in distilled water was sonicated for $10 \mathrm{~min}$, and then heated at $90^{\circ} \mathrm{C}$ for $2 \mathrm{~h}$ in a water bath. The freeze drying was used to keep the porous structure. The r-GO foam was prepared by the same method of $\mathrm{ZnS} / \mathrm{r}-\mathrm{GO}$ for a contract.

Preparation of the ZnS/S, r-GO/S and ZnS/r-GO/S composites. The ZnS/S, r-GO/S and ZnS/r-GO/S composites were prepared by the conventional melt-diffusion method. Typically, sulfur powders and the samples $(\mathrm{ZnS}, \mathrm{r}-\mathrm{GO}$ or $\mathrm{ZnS} / \mathrm{r}-\mathrm{GO})$ in a mass ratio of $3: 2$ were homogenized by ground in an agate mortar. The mixtures were sealed in $25 \mathrm{~mL}$ Teflon-lined stainless-steel autoclave with argon in glove box, maintained at $155^{\circ} \mathrm{C}$ for $12 \mathrm{~h}$. 


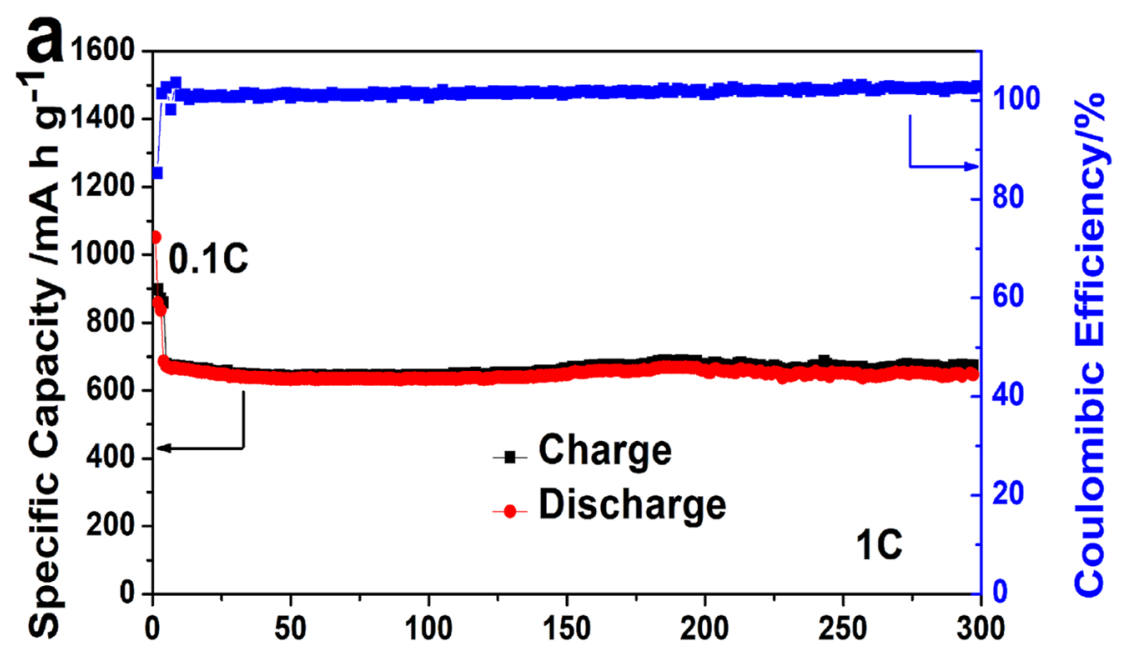

Cvcle Number
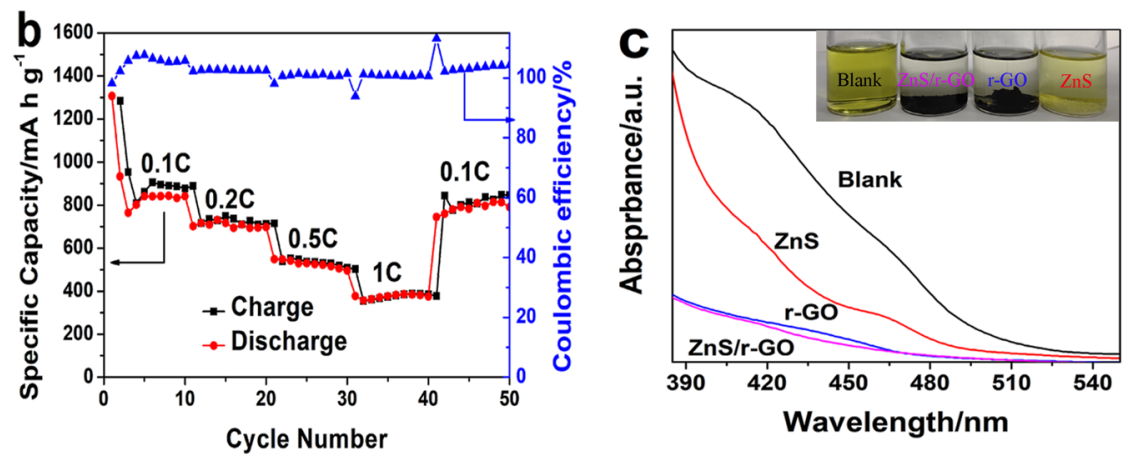

Figure 6. Electrochemical performance and Polysulfides adsorption. (a) Long-term cycling performance of $\mathrm{ZnS} / \mathrm{r}-\mathrm{GO} / \mathrm{S}$ at $1 \mathrm{C}$ after activation in first three cycles at $0.1 \mathrm{C}$. (b) Rate capacity of $\mathrm{ZnS} / \mathrm{r}-\mathrm{GO} / \mathrm{S}$, (c) UV-vis spectra of the $\mathrm{Li}_{2} \mathrm{~S}_{6}$ solution with blank, $\mathrm{ZnS}, \mathrm{r}-\mathrm{GO}$ and $\mathrm{ZnS} / \mathrm{r}-\mathrm{GO}$. (Inset photograph of visualized adsorption of $\mathrm{Li}_{2} \mathrm{~S}_{6}$ on $\mathrm{ZnS}$, r-GO and $\mathrm{ZnS} / \mathrm{r}-\mathrm{GO}$ with same mass).

Characterization. SEM images were obtained with a scanning electron microscope. TEM and high-resolution TEM (HRTEM) images were performed by a transmission electron microscopy at $200 \mathrm{KV}$. The $\mathrm{X}$-ray diffraction measurements were carried out using an X-ray powder diffractometer, performed in transmission geometry with $\mathrm{Cu} \mathrm{K} \mathrm{K}_{\alpha 1}$ radiation $\left(\lambda=1.5418 \AA\right.$ ). The samples were measured at the sweep rate of $5^{\circ} \mathrm{min}^{-1}$. X-ray photoelectron spectroscopy (XPS) measurements were performed on a Kratos XSAM 800 (UK). UV-vis spectra of the $\mathrm{Li}_{2} \mathrm{~S}_{6}$ solutions exposed to different adsorbents were collected on a UV-vis spectrometer. The sulfur contents of composites were determined using thermo-gravimetry analyses (TGA) on a DTG-60 from the room temperature to $800^{\circ} \mathrm{C}$ with a heating rate of $10^{\circ} \mathrm{C} \mathrm{min}-1$ in $\mathrm{Ar}$.

Polysulfides adsorption tests. Lithium polysulfide $\left(\mathrm{Li}_{2} \mathrm{~S}_{6}\right)$ solution was prepared as the literature reported ${ }^{19}$. The stoichiometric ratio amounts of sublimed sulfur and lithium sulfide $\left(\mathrm{Li}_{2} \mathrm{~S}\right)$ with a molar ratio of 5:1 were dissolved in 1:1 (v/v) DOL/DME, then sealed in an argon-filled glove box, stirred at $60^{\circ} \mathrm{C}$ for $48 \mathrm{~h}$ in the ambient environment. $10 \mathrm{mg}$ the $\mathrm{ZnS}$, r-GO or $\mathrm{ZnS} / \mathrm{r}-\mathrm{GO}$ was added in an $8 \mathrm{ml} \mathrm{Li}_{2} \mathrm{~S}_{6}$ solution $\left(1 \mathrm{mmol} \mathrm{L}^{-1}\right)$ and stewed for $24 \mathrm{~h}$. The UV-vis spectra were tested to analyze the adsorption ability of the $\mathrm{ZnS}, \mathrm{r}-\mathrm{GO}$ or $\mathrm{ZnS} / \mathrm{r}-\mathrm{GO}$ for $\mathrm{Li}_{2} \mathrm{~S}_{6}$.

Cell assembly and electrochemical measurements. The electrochemical tests were performed using a coin type 2032 half-cell with lithium metal (purity 99.95\%, $0.6 \mathrm{~mm}$ thick and $15.8 \mathrm{~mm}$ in diameter) as counter and reference electrodes, and the polypropylene films (Ceglard 2400) were as separators. The electrode slurry was composed of 80 wt. \% active materials (the ZnS/S, r-GO/S or ZnS/r-GO/S), 10 wt. \% acetylene black and 10 wt. $\%$ polyvinylidene fluoride (PVDF), moderate n-methyl-2-pyrrolidinone (NMP) as solvent. The active materials and acetylene black, PVDF were ground uniformly in an agate mortar for $1 \mathrm{~h}$. The slurry was coated onto carbon paper (thickness of $20 \mu \mathrm{m}$ ) with subsequent heating at $60^{\circ} \mathrm{C}$ for $24 \mathrm{~h}$ in vacuum. The composite carbon paper was then punched into disk with $14.2 \mathrm{~mm}$ in diameter to be used as cathodes. The areal sulfur loadings were ranged at $1.3 \sim 2.2 \mathrm{mg} \mathrm{cm}^{-2} .1 \mathrm{~mol} \mathrm{~L}^{-1}$ lithium bistrifluoromethyl sulfimide (LiTFSI) in DME and DOL (1:1 v/v) with 2 wt. \% $\mathrm{LiNO}_{3}$ was used as the electrolyte. The galvanostatic charge/discharge performance of the cells was tested on a multichannel battery tester (LANDCT) in the potential range of $1.7 \sim 2.7 \mathrm{~V} \mathrm{vs.} \mathrm{Li}^{+} / \mathrm{Li}$ electrodes at room temperature. Cyclic Voltammetry (CV) measurements were performed at a scan rate of $0.1 \mathrm{mV} \mathrm{s}^{-1}$ on an electrochemical workstation. Applied currents and specific capacities were calculated on the basis of the mass ratio of $S$ in the cathodes. 
Received: 11 October 2019; Accepted: 6 March 2020;

Published online: 24 March 2020

\section{References}

1. Manthiram, A., Fu, Y. \& Su, Y.-S. Challenges and peospects of lithium sulfur batteries. Acc. Chem. Res. 46, 1125-1134 (2013).

2. Yin, Y. X., Xin, S., Guo, Y. G. \& Wan, L. J. Lithium-sulfur batteries: electrochemistry, materials, and prospects. Angew. Chem. Int. Ed. Engl. 52, 13186-13200, https://doi.org/10.1002/anie.201304762 (2013).

3. Bu, Y. et al. Sandwich-type porous carbon/sulfur/polyaniline composite as cathode material for high-performance lithium-sulfur batteries. RSC Adv. 6, 104591-104596, https://doi.org/10.1039/c6ra23943a (2016).

4. Xiang, K., Cai, S., Wang, X., Chen, M. \& Jiang, S. Nitrogen-doped activated microporous carbon spheres as a sulfur matrix for advanced lithium-sulfur batteries. J. Alloy. Compd. 740, 687-694, https://doi.org/10.1016/j.jallcom.2018.01.026 (2018).

5. Pope, M. A. \& Aksay, I. A. Structural design of cathodes for Li-S batteries. Adv. Energy Mater. 5, 1500124, https://doi.org/10.1002/ aenm.201500124 (2015).

6. Manthiram, A., Fu, Y., Chung, S. H., Zu, C. \& Su, Y. S. Rechargeable lithium-sulfur batteries. Chem. Rev. 114, 11751-11787, https:// doi.org/10.1021/cr500062v (2014).

7. Li, X., Wang, Y., Xu, C. \& Pan, L. Mesoporous carbon/sulfur composite with N-doping and tunable pore size for high-performance Li-S batteries. J. Solid. State Electrochem. 21, 1101-1109, https://doi.org/10.1007/s10008-016-3453-7 (2016).

8. Wei, H. et al. Chemical bonding and physical trapping of sulfur in mesoporous Magnéli $\mathrm{Ti}_{4} \mathrm{O}_{7}$ microspheres for high-performance Li-S battery. Adv. Energy Mater. 7, 1601616, https://doi.org/10.1002/aenm.201601616 (2017).

9. He, J., Luo, L., Chen, Y. \& Manthiram, A. Yolk-shelled C@ $\mathrm{Fe}_{3} \mathrm{O}_{4}$ nanoboxes as efficient sulfur hosts for high-performance lithiumsulfur batteries. Adv. Mater 29, https://doi.org/10.1002/adma.201702707 (2017).

10. Chen, S. R. et al. Ordered mesoporous carbon/sulfur nanocomposite of high performances as cathode for lithium-sulfur battery. Electrochim. Acta 56, 9549 (2011).

11. Zhao, Q. et al. A 3D conductive carbon interlayer with ultrahigh adsorption capability for lithium-sulfur batteries. Appl. Surf. Sci. 440, 770-777, https://doi.org/10.1016/j.apsusc.2018.01.162 (2018).

12. Chen, R. et al. Graphene-based three-dimensional hierarchical sandwich-type architecture for high-performance Li/S batteries. Nano Lett. 13, 4642-4649, https://doi.org/10.1021/nl4016683 (2013).

13. Zhang, Y. et al. The construction of high sulfur content spherical sulfur-carbon nanotube-polyethylene glycol-nickel nitrate hydroxide composites for lithium sulfur battery. J. Alloy. Compd. 729, 331-337, https://doi.org/10.1016/j.jallcom.2017.09.131 (2017).

14. Yin, L., Wang, J., Yang, J. \& Nuli, Y. A novel pyrolyed polyacrylonitrile-sulfur@MWCNT composite cathode material for high-rate rechargeable lithium/sulfur batteries. J. Mater. Chem. 21, 6807 (2011).

15. Li, H. et al. Three-dimensionally ordered hierarchically porous polypyrrole loading sulfur as high-performance cathode for lithium/ sulfur batteries. Polym. 137, 261-268, https://doi.org/10.1016/j.polymer.2018.01.022 (2018).

16. Wei Seh, Z. et al. Sulphur-TiO 2 yolk-shell nanoarchitecture with internal void space for long-cycle lithium-sulphur batteries. Nat. Commun. 4, 1331, https://doi.org/10.1038/ncomms2327 (2013).

17. Demir-Cakan, R. et al. Cathode composites for Li-S batteries via the use of oxygenated porous architectures. J. Am. Chem. Soc. 133, 16154 (2011)

18. Cha, E. et al. $2 \mathrm{D} \mathrm{MoS}_{2}$ as an efficient protective layer for lithium metal anodes in high-performance Li-S batteries. Nat. Nanotechnol. 13, 337-344, https://doi.org/10.1038/s41565-018-0061-y (2018).

19. Lei, T. et al. Multi-functional layered $\mathrm{WS}_{2}$ nanosheets for enhancing the performance of lithium-sulfur batteries. Adv. Energy Mater. 7, 1601843, https://doi.org/10.1002/aenm.201601843 (2017).

20. Zhang, L. et al. High-content of sulfur uniformly embedded in mesoporous carbon: a new electrodeposition synthesis and an outstanding lithium-sulfur battery cathode. J. Mater. Chem. A 5, 5905-5911, https://doi.org/10.1039/c7ta00328e (2017).

21. Zhang, X.-Q., He, B., Li, W.-C. \& Lu, A.-H. Hollow carbon nanofibers with dynamic adjustable pore sizes and closed ends as hosts for high-rate lithium-sulfur battery cathodes. Nano Res. 11, 1238-1246, https://doi.org/10.1007/s12274-017-1737-6 (2018).

22. Zhang, Y., Sun, L., Li, H., Tan, T. \& Li, J. Porous three-dimensional reduced graphene oxide for high-performance lithium-sulfur batteries. J. Alloy. Compd. 739, 290-297, https://doi.org/10.1016/j.jallcom.2017.12.294 (2018).

23. Wang, F., Wang, H. \& Mao, J. Aligned-graphene composites: a review. J. Mater. Sci. 54, 36-61, https://doi.org/10.1007/s10853-0182849-4 (2019).

24. Tao, X. et al. Balancing surface adsorption and diffusion of lithium-polysulfides on nonconductive oxides for lithium-sulfur battery design. Nat. Commun. 7, https://doi.org/10.1038/ncomms11203 (2016).

25. Liang, X. \& Nazar, L. F. In situ reactive assembly of scalable core-shell sulfur-MnO $\mathrm{Mn}_{2}$ composite cathodes. ACS Nano 10, 4192-4198, https://doi.org/10.1021/acsnano.5b07458 (2016).

26. Liu, X., Huang, J. Q., Zhang, Q. \& Mai, L. Nanostructured metal oxides and sulfides for lithium-sulfur batteries. Adv. Mater. 29, https://doi.org/10.1002/adma.201601759 (2017)

27. Gao, C. et al. Rational design of multi-functional CoS@rGO composite for performance enhanced Li-S cathode. J. Power Sources 421, 132-138, https://doi.org/10.1016/j.jpowsour.2019.03.015 (2019).

28. Yu, S. H. \& Yoshimura, M. Shape and phase control of ZnS nanocrystals: Template fabrication of wurtzite ZnS single-crystal nanosheets and $\mathrm{ZnO}$ flake-like dendrites from a lamellar molecular precursor $\mathrm{ZnS}-\left(\mathrm{NH}_{2} \mathrm{CH}_{2} \mathrm{CH}_{2} \mathrm{NH}_{2}\right)(0.5)$. Adv. Mater. 14, 296-+, doi:10.1002/1521-4095(20020219)14:4<296::aid-adma296>3.3.co;2-y (2002).

29. Ni, Y. H. et al. Preparation, conversion, and comparison of the photocatalytic and electrochemical properties of $\mathrm{ZnS}(\mathrm{en})(0.5), \mathrm{ZnS}$, and ZnO. Cryst. Growth Des. 7, 280-285, https://doi.org/10.1021/cg060312z (2007).

30. Xu, J. et al. Promoting lithium polysulfide/sulfide redox kinetics by the catalyzing of zinc sulfide for high performance lithium-sulfur battery. Nano Energy 51, 73-82, https://doi.org/10.1016/j.nanoen.2018.06.046 (2018).

31. Chen Long, L. J.-D. \& Zhang S.-Q. Preparation of mesoporous carbon/sulfur composite loaded with ZnS and its property for lithium-sulfur batteries. J. Inorg. Mater., 1127 (2017).

32. Liu, J. et al. Novel porous single-crystalline $\mathrm{ZnO}$ nanosheets fabricated by annealing $\mathrm{ZnS}(\mathrm{en})_{0.5}$ (en $=$ ethylenediamine) precursor. Application in a gas sensor for indoor air contaminant detection. Nanotechnol. 20, 125501, https://doi.org/10.1088/0957$4484 / 20 / 12 / 125501$ (2009).

33. Ouyang, X. et al. Ab initio structure study from in-house powder diffraction of a novel $\mathrm{ZnS}(\mathrm{EN})_{0.5}$ structure with layered wurtzite ZnS fragment. Chem. Comm., 886-887, https://doi.org/10.1039/b212335p (2003).

34. Jang, J. et al. Topotactic synthesis of mesoporous $\mathrm{ZnS}$ and $\mathrm{ZnO}$ nanoplates and their photocatalytic activity. J. Catal. 254, 144-155, https://doi.org/10.1016/j.jcat.2007.12.010 (2008).

35. Xu, C., Wang, X. \& Zhu, J. W. Graphene-metal particle nanocomposites. J. Phys. Chem. C. 112, 19841-19845, https://doi. org/10.1021/jp807989b (2008).

36. Golsheikh, A. M., Lim, H. N., Zakaria, R. \& Huang, N. M. Sonochemical synthesis of reduced graphene oxide uniformly decorated with hierarchical $\mathrm{ZnS}$ nanospheres and its enhanced photocatalytic activities. RSC Adv. 5, 12726-12735, https://doi.org/10.1039/ c4ra14775h (2015). 
37. Chu, K., Liu, Y. P., Li, Y. B., Wang, J. \& Zhang, H. Electronically coupled $\mathrm{SnO}_{2}$ quantum dots and graphene for efficient nitrogen reduction reaction. ACS Appl. Mater. Interfaces 11, 31806-31815, https://doi.org/10.1021/acsami.9b08055 (2019).

38. Razaq, R. et al. Ultrahigh sulfur loading in $\mathrm{ZnS}_{1-\mathrm{x}} / \mathrm{rGO}$ through in situ oxidation-refilling route for high-performance Li S batteries. J. Power Sources 414, 453-459, https://doi.org/10.1016/j.jpowsour.2019.01.038 (2019).

39. Liu, J., Chen, H., Chen, W., Zhang, Y. \& Zheng, Y. New insight into the "shuttle mechanism" of rechargeable lithium-sulfur batteries. ChemElectroChem 6, 2782-2787, https://doi.org/10.1002/celc.201900420 (2019).

\section{Acknowledgements}

The work was supported by the Sichuan Science and Technology Program (2018GZ0459 and 2017GZ0108).

\section{Author contributions}

Jian Mao designed the research. Limin Mao conducted the experiments and deal with the results and discussions with Fei Wang. Limin Mao wrote the draft of the manuscript.

\section{Competing interests}

The authors declare no competing interests.

\section{Additional information}

Correspondence and requests for materials should be addressed to J.M.

Reprints and permissions information is available at www.nature.com/reprints.

Publisher's note Springer Nature remains neutral with regard to jurisdictional claims in published maps and institutional affiliations.

(c) (i) Open Access This article is licensed under a Creative Commons Attribution 4.0 International License, which permits use, sharing, adaptation, distribution and reproduction in any medium or format, as long as you give appropriate credit to the original author(s) and the source, provide a link to the Creative Commons license, and indicate if changes were made. The images or other third party material in this article are included in the article's Creative Commons license, unless indicated otherwise in a credit line to the material. If material is not included in the article's Creative Commons license and your intended use is not permitted by statutory regulation or exceeds the permitted use, you will need to obtain permission directly from the copyright holder. To view a copy of this license, visit http://creativecommons.org/licenses/by/4.0/.

(C) The Author(s) 2020 